International Conference:

Nineteenth and Twentieth Century Philological Encounters

Joint International Conference of the research program ZUKUNFTSPHILOLOGIE, the LEIDEN UNIVERSITY CENTRE FOR THE STUDY OF ISLAM AND SOCIETY (LUCIS) and the CNRS Paris, in cooperation with LEIDEN UNIVERSITY LIBRARY, FREIE UNIVERSITÄT BERLIN and the UNIVERSITY OF UTRECHT

\author{
4 - 5 June 2014 (Leiden, the Netherlands) \\ Convened by \\ Islam Dayeh (Zukunftsphilologie/Freie Universität Berlin) \\ Umar Ryad (University of Utrecht) \\ Pascale Rabault-Feuerhahn (CNRS Paris)
}

\title{
Description
}

As a result of colonial expansion and the technologies that made long-distance communication and travel possible, the 19th and 20th centuries witnessed an accelerated rate of individual interactions across the globe, including scholarly encounters. Individual scholars became more conscious of the commonalities that they shared with fellow humans all over the world, which they expressed in universalistic projects in philosophy, philology, the life sciences and other fields of human inquiry. Yet the encounter also brought about an articulation of differences. Nineteenth and Twentieth Century Philological Encounters is a conference dedicated to exploring the personal (and especially self-reflective) dimensions of academic knowledge production by studying scholars (i.e., producers) and their contexts (i.e., institutions and societies) in relation to their objects of study.

Knowledge is always embedded in institutions and is produced by individual scholars whose choices are shaped by their biographies as much as by the subjects they study. Thus, Philological Encounters refers to the discovery of difference that came about due to the real-life encounters between professionals and interpreters of texts, languages and cultures across the globe. This conference outlines an avenue of research dedicated to the study of tensions, antagonisms and polemics - as well as fascination, cooperation, appropriation and friendship - that transpired as a consequence of the meetings of different scholars and their dissimilar modes of textual scholarship, made possible through international cooperation in the form of conferences, journals, academic associations and student exchange. 


\section{Zukunftsph ilologie}

The conference objective is not hagiography, but rather historicizing seemingly monolithic categories - such as 'orientalism', 'philology' and 'history' - by localizing the role of individual actors in the process of knowledge formation, in the colonial and post-colonial periods. The conference addresses this by looking at first-person accounts of conferences, reports, travel writing, correspondences, memoirs, auto/biographies, polemical essays, and translations, among other writings.

In cooperation with
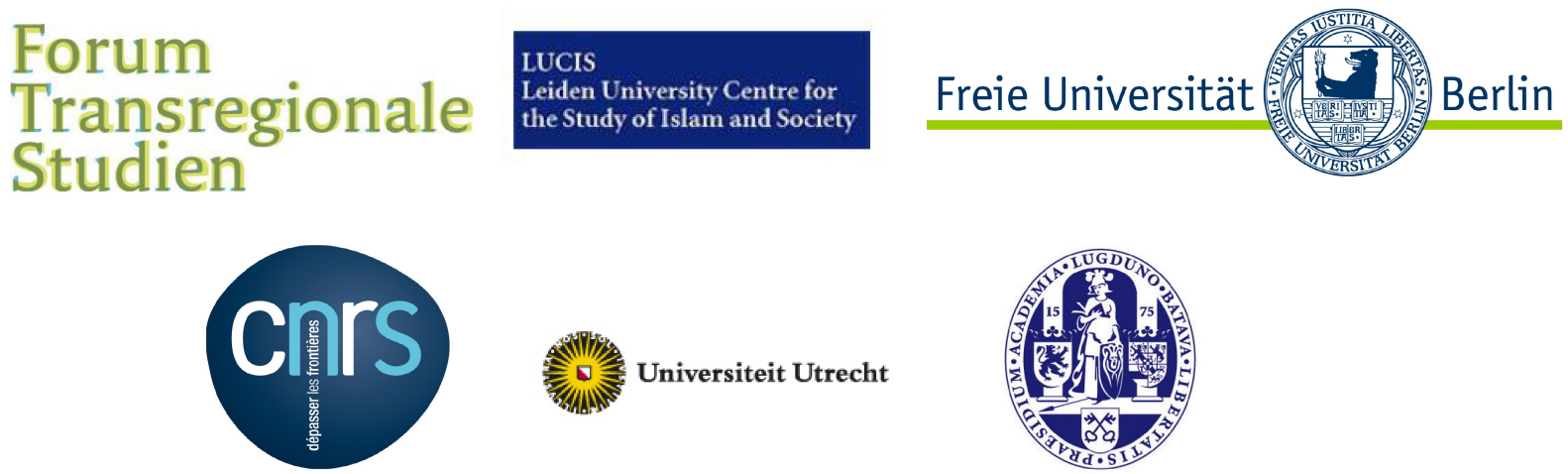

UMR 8547 Pays germaniques

\section{Universiteit Leiden}




\section{Zukunftsph ilologie}

\section{Schedule}

Wednesday, 4 June 2014

Venue: $\quad$ Main conference room (Universiteitsbibliotheek, Witte Singel 27)

09.45-10.15 Introduction

Islam Dayeh, Umar Ryad and Pascale Rabault-Feuerhahn

Leon Buskens (LUCIS - Director)

Arnold Vrolijk (Library of the University of Leiden - Curator of Oriental Manuscripts and

Rare Books)

Chair: Umar Ryad (Utrecht University)

10.15-11.00 Albert de Jong (Leiden Institute for Religious Studies)

Lawrence Heyworth Mills (1837-1918) and his Zoroastrian Catechism

11.00-11.45 Mishka Sinha (Zukunftsphilologie Fellow 2013-2014, Berlin)

"And shall all these die for me and mine?" A new Ethics for the Gita: Josiah Royce, Indic Philology and Post-Kantian Idealism in the United States, 1876-1916

11.45-12.00 Coffee Break

Chair: Pascale Rabault-Feuerhahn (CNRS Paris)

$12.00-12.45$ Thibaut d'Hubert (Zukunftsphilologie Fellow 2013-2014, Berlin/University of Chicago) John Murray, 'a Highland Chieftain elevated by Oriental Ideas'

$12.45-13.30$ Sarath Jakka (University of Porto/University of Kent) Philological/Pedagogical Encounters: Charles Philip Brown and his Encounter with the Telugu Language

$13.30-14.45 \quad$ Lunch

Chair: Pascale Rabault-Feuerhahn (CNRS Paris)

14.45-15.30 Andrés Jiménez-Ángel (Katholische Universität Eichstätt-Ingolstadt)

Correspondence, "Cultural Pilgrimage" and the Transnational Legitimation of Philological and Linguistic Knowledge in Colombia, 1876-1911 


\section{Zukunftsph ilologie}

15.30 - 16.15 Pablo Martínez (Universidad de Buenos Aires)

Unencountered Philologists: Ricardo Rojas and the Spanish Directors of the Institute of Philology at the University of Buenos Aires

16.15-16.30 Coffee Break

Chair: Islam Dayeh (Freie Universität Berlin)

16.30 - 17.15 Ammeke Kateman (University of Amsterdam)

Discussing Religion Globally. An Encounter between Muhammad 'Abduh, Herbert

Spencer and Wilfrid Blunt

17.15-18.00 Dyala Hamzah (University of Montréal)

History at a Crossroad. Early Arab Nationalist Narratives, American and German

Orientalism and the Legacies of Islamic Historiography

Thursday, 5 June 2014

Chair: Umar Ryad (Utrecht University)

10.00 - 10.45 Göran Larsson (University of Gothenburg)

H.S. Nyberg's Encounter with Egypt and the Mu'tazili School of Thought

10.45-11.30 Elisabetta Benigni (University of Turin)

Italian Orientalists in Cairo: The Case of Ignazio Guidi and his Son Michelangelo

11.30-11.45 Coffee Break

Chair: Pascale Rabault-Feuerhahn (CNRS Paris)

$11.45-12.30 \quad$ Michael Facius (Freie Universität Berlin)

Transcultural Sinology in late 19th-Century Japan. The Case of Shigeno Yasutsugu

$12.30-13.15 \quad$ Rico Sneller (Leiden University)

Heidegger and the Japanese Notion of 'Language'

$13.15-14.30 \quad$ Lunch 


\section{Zukunftsph ilologie}

Chair: Islam Dayeh (Freie Universität Berlin)

$14.30-15.15$ Sherif Hasan Ismail (New York University)

Philological Encounters, Literary Reconstructions: Fāris al-Shidyāq and His Career

15.15-16.00 Herman Paul (Leiden University)

Contested Visions of Oriental Studies: The Polemical Reception of Reinhart Dozy's 'The

Israelites in Mecca' in the 1860s

16.00-16.15 Coffee Break

Chair: Islam Dayeh (Freie Universität)

16.15-17.00 Tal Hever-Chybowski (Humboldt Universität zu Berlin)

The 'Zamlers' Scholarly Model: Mobilizing the East-European Jewish Masses for

Philological Projects

17.00-17.45 Concluding Discussion 


\title{
Zukunftsph ilologie
}

\section{Abstracts and short biographies}

\author{
Elisabetta Benigni \\ (University of Turin) \\ Italian Orientalists in Cairo: the Case of Ignazio Guidi and his Son Michelangelo
}

Cairo University was founded in Giza on December 21, 1908. In that same year, the Italian orientalist Ignazio Guidi (Rome 1844 - Rome 1935) was appointed by the Egyptian University for a semester to teach literature, history and geography. During that semester, Ignazio Guidi left his position as Professor of Hebrew and Comparative Semitic Languages at the University of Rome, and gave at the Cairo University 40 lessons in fluent Arabic. After this successful experience, an entire generation of Italian Orientalists, particularly philologists and scholars of Arabic literature taught in the same University. After the first skepticism of the local students (as testified in the letters of Carlo Alfonso Nallino), the Italian scholars were fully recognized as integral part of Egyptian cultural life, and engaged with local scholars and intellectuals in intense debate, sometimes testified by letters, as in the famous case of the exchange between Nallino and Taha Hussain. My paper aims to look at this generation of Italian orientalists particularly focusing on the two figures of Ignazio Guidi and his son Michelangelo (Rome 1886- 1946). Despite their important contributions to the field of Oriental studies, these two figures remain less known than their colleagues who also taught in Cairo University (like David Santillana, Carlo Alfonso Nallino and Gerardo Meloni). In particular, Michelangelo Guidi, who taught in Cairo from 1926 to 1929, deserves particular attention. Having inherited from his father the interest in Oriental studies, Michelangelo differs from his colleagues who devoted their attention to Arabic literature and culture with a specific philological and rationalistic attitude. Along with its interests in texts and languages, he also explored the field to heresiology and studies of comparative religion dealing with the major historical debates that were current at that time and demonstrated original attitudes such as his Umanesimo e Orientalismo (Humanism and Orientalism), which echoes his debate with Taha Hussain about the Greek influence on Arabic rhetoric (see Badawi, Mawsu'at al-Mustashriqin). His writings, together with the correspondence that he and his fellow Italian scholars entertained among them and with other scholars (in and outside Cairo) during their stay in Egypt will be used as primary source in order to discuss the global questions raised in a period of mutual Mediterranean contacts.

Elisabetta Benigni is Assistant Professor of Arabic language and literature at the University of Turin. After having obtained her PhD from the University Sapienza (Rome) in 2009, Elisabetta Benigni was postdoctoral fellow at the research programme Zukunftsphilologie at Freie Universitat in Berlin (2011-2012) and an Herzog-Ernst Thyssen Foundation postdoctoral fellow at the Gotha research library (2012). Her research interests are comparative literature in the Mediterranean context (particularly focusing on the transmission of texts in the early modern Mediterranean world) and exchanges and relations between Italian and Arab intellectual worlds. She has also worked on prison literature in Arabic (Il carcere come spazio letterario, Nuova Cultura, 2009), the Arabic translations of Dante's Commedia («La Divina Commedia nel mondo 


\section{Zukunftsph ilologie}

arabo: studi, orientamenti critici e traduzioni», Critica del testo , 2011) and the image of Jerusalem in Medieval and modern Arabic literature («Il realismo immaginario di Gerusalemme» in E. Benigni, M. Marconi, D. Salemi, Quattro studi su Gerusalemme, Nuova Cultura, 2012).

\section{Islam Dayeh - convener}

(Freie Universität Berlin)

Islam Dayeh is director of the research program Zukunftsphilologie. Islam Dayeh studied at the University of Jordan (BA in Islamic studies), University of Leiden (MA in Religious Studies) and University of Oxford (MSt in Jewish studies). He completed his PhD dissertation in Arabic philology at Freie Universität Berlin under the supervision of Angelika Neuwirth. His research interests focus on comparative philology, commentary cultures and text-editing practices in European and Arabic textual traditions. He investigates the emergence of the discipline of "Semitic philology" (Semitistik) and its introduction in the Arabic language academies and curricula of the 19th and 20th centuries and the impact of European constructions of Semitic race, language, and religion on Arab philologists of the 19th and 20th centuries. In relation to this, his research engages with the development of historicist methodologies in the study of the Bible (Bibelwissenschaft) and their applicability, given their rootedness in particular hermeneutical traditions, to the Qur'an. Dayeh situates his research in a broader context of the intellectual and cultural entanglements that have shaped relations between Europe and the Arabic-Islamic world from the medieval period to this day.

\section{Thibaut d'Hubert}

(Zukunftsphilologie Fellow 2013-2014, Berlin/University of Chicago)

John Murray, 'a Highland Chieftain elevated by Oriental Ideas'

In this paper I propose to study the career of John Murray MacGregor (1745-1822) and his collaboration with his Persian secretaries. I will look at the formative period of British Orientalism in Bengal, focusing on texts that resulted from the collaboration between John Murray, a Scottish officer of the East India Company, and Bengal's Indo-Persian and vernacular literati. I propose to study the textual practices involved in this collaborative work in connection with the social and philosophical context of eighteenth century Britain and Mughal India.

John Murray was a founding member of both the Highland Society and the Asiatic Society of Bengal. He spent substantial amounts of the money he earned as an officer in India to foster the study of Scottish Gaelic language and literature. He also commissioned several texts on Hinduism, Buddhism, law, agriculture, history and surveys on Bengal and the neighboring regions of Bihar and Arakan (in today's Myanmar). He also left a large correspondence in Persian and Bengali that allows us to explore the relations he had with the elites of Mughal India, and particularly of Bengal. Based on this voluminous archive I will attempt to give a contextualized account of John Murray's career. I will focus on his views about the retrieving and preservation of his own Gaelic cultural heritage, and his endeavor to systematically discover Bengal and 


\section{Zukunftsph ilologie}

Arakan's cultural traditions. In his exploration of the cultures of these regions Murray was guided by Muslim/secretaries who were themselves working with Hindu Pandits and Buddhist monks. Murray's archives are therefore the product of a collective effort involving multiple layers of translation, the convergence of several scholarly traditions and of individual voices that must be recovered in order to better understand the intellectual relations between South Asia and Europe in the late 18th and early 19th centuries.

Thibaut d'Hubert completed his PhD at the Historical and Philological Sciences section of the École Pratique des Hautes Études in Paris in 2010 and then joined the department of South Asian Literatures and Civilizations of the University of Chicago. His research focuses on premodern literary cultures in Bengal, with a special emphasis on translations involving Bengali and Persian. In the framework of the program, Thibaut explores the archive of John Murray MacGregor (1745-1822), a Scottish officer who was instrumental in the foundation of learned societies in England, Scotland and Bengal in the late 18th century. The interpretation of this archive entails a twofold project. The first part is the reconstitution of Murray's biography based on his English, Persian and Bengali correspondence. The second part looks at Persian translations of Buddhist texts from Arakan (in modern Myanmar) commissioned by Murray. Thibaut studies the cultural layers visible in the process of translation of the Buddhist texts by Murray's secretaries 'Azīz Allāh Bukhārī and Sādiq Alī. The project as a whole explores the paths linking textual practices and scholarly traditions from Burma to Scotland on the eve of colonialism.

\section{Michael Facius}

(Freie Universität Berlin)

\section{Transcultural Sinology in late 19th-Century Japan. The Case of Shigeno Yasutsugu}

In Meiji-period Japan (1868-1912), the status of knowledge of the classical written language of China changed dramatically from the foundation of all higher learning to a specialist philology. In the early Meiji years in particular, the new regime uprooted much of the epistemic culture of the preceding Tokugawa period and replaced it with an academic and disciplinary system based on Western precedents.

The paper spotlights Shigeno Yasutsugu (1827-1910) as a transcultural actor. Shigeno bridged the old and new worlds of Chinese scholarship. Before the Meiji restoration, he had studied at the prestigious Shōheikō in Edo (today Tokyo), the official school of the Tokugawa government, and served as a professor at the domain school in Satsuma. Under the new government, he was appointed to the Historiographical Office, became professor at the University of Tokyo and was instrumental in establishing History as an academic discipline. Shigeno was positioned in a transcultural space in many respects: his activities spanned different epistemic traditions, politics and the academy, as well as diverse disciplines and languages. While he stayed in Tokyo for most of his later life and visited China only once, his research interests and concerns as well as his personal networks were very much shaped by Japan's integration into the emerging global order of the 19th century. 


\section{Zukunftsph ilologie}

The paper explores some of the threads in Shigeno's knowledge production traceable to transcultural scholarly encounters such as the influence of Ludwig Riess, a student of Leopold von Ranke, on Shigeno's methodology or his contacts with Chinese diplomats and literati.

Michael Facius received his M.A. in Japanese Studies and Linguistics from Bonn University in 2008. From 2008 to 2012 he was a member of the Research Training Group "Actors of cultural globalization, 1860-1930" at Freie Universität Berlin. Currently he is preparing his doctoral thesis on "Translating China: Globalization and Chinese knowledge in 19th century Japan" for submission. Since 2013, he is member of the DFG-funded Collaborative Research Center "Epistemes in motion", also at Freie Universität Berlin with a research project on the origins of Early Modern Japan in a global historical perspective.

\section{Pablo Martínez}

(Universidad de Buenos Aires)

Unencountered Philologists: Ricardo Rojas and the Spanish Directors of the Institute of Philology at the University of Buenos Aires

The scholarly biography of Ricardo Rojas (1882-1957) is a crossroad of personal scientific achievement, institutional foundations, and versions of Argentine national identity. As a young official, the government sent him in a long study trip in 1907 to evaluate the teaching of history in Germany, France, England, Italy, and Spain. He elaborated a proposal of mandatory national history classes in order to "Argentinize" the enormous number of immigrants and their descendant, in a relatively new state-nation. Just a few years later, he was named the first national literature professor at the university level (1912), he wrote the first history of Argentine literature (1917-1922), and he created the research Institutes of Argentine Literature (1922) and of Hispanic Philology (1923) at the Universidad de Buenos Aires, the largest and most prestigious of the country. Following the dictates of the philology learned and explored during his trip, he elaborated a view of Argentine nationhood that closely resembled the ideal of the folk upheld by German romanticism.

In this paper, based on Rojas's travel writings and abundant epistolary, as well as his own critic works, we will study his relationship with several European philologists (especially with Ramón Menéndez Pidal) during the 1910s and 1920s, in which the formation of a philological field in Argentine was "tutored" by their European counterparts. During the four first years of existence of the Philology Institute, its directors were yearly sent from Menéndez Pidal's research centre in Madrid, and that position was held by foreigners until 1955. However, the Institute strongly collaborated with Rojas and other nationalist intellectuals' general project of finding, establishing, and ordering (thus, ultimately, creating) a "national culture", centered on a national literature, studied through the powerful lens of modern philology. Import of philology, then, was also an import of philologists, in order to give a cultural foundation to the liberal state consolidated in the late 19th century. 


\section{Zukunftsph ilologie}

Pablo Martínez obtained a bachelor's degree (licenciatura) in Literature and Linguistics at Universidad de Buenos Aires and a master's degree in Social Sciences at the Universidad Nacional de Luján. He has taught at different universities in Argentina and the United States. He also obtained fellowships at the Argentine National Council of Research (CONICET). Currently, he teaches Spanish Literature at a high school professors' training institution and Latin American Intellectual History at Universidad de Buenos Aires. His doctoral dissertation, currently in its final stage, is about reading and writing before and after Argentine Independence Revolution. A book about Argentine literary canon formation is forthcoming.

\section{Dyala Hamzah}

(University of Montreal)

History at a Crossroad. Early Arab Nationalist Narratives, American and German Orientalism and the Legacies of Islamic Historiography

How did one go about devising teaching material in the 1920s and 1930s Middle East? Philip Hitti, the father of Middle East Studies in the U.S.A. and formerly professor of 'Oriental history' at the Syrian Protestant College in Beirut, remembered the years he was lecturing there as conspicuously lacking in textbooks, research facilities and reference works. He himself had written a PhD in Arab history without having ever been lectured, at the SPC or at Columbia, on that subject. "Arab history", he said, "was not taught in Beirut." What methodologies did Hitti rely on to engineer the new discipline of 'Oriental history'? What new sources did he conjure up and how did the stuff of premodern chronicles get transformed in the process? Sati' al-Husri, the architect of the modern Iraqi schooling system relied on imported French models formerly in use at Istanbul's academies. Was it therein that he devised a pedagogy for distinguishing between useful knowledge and knowledge for its own sake? This paper focuses on one pioneering Arab historian, himself a student of Hitti and a functionary under Husri, as he articulated in school textbooks the passage from local patriotism (wataniyya) to nationalism (qawmiyya), and from Islamic historiography to the modern discipline of history. Darwish al-Miqdadi (1897-1961) coauthored with Akram Zu'aytar his first primary school textbook, Tarikhuna bi uslub qisasi (1st ed. 1935) and went on to write single- handedly his secondary school textbook Tarikh al-umma al-'arabiyya (1st ed. 1936). The paper interrogates the craft of the new historian by probing him dialectically at work with his masters, old and new. It looks at the subsequent editions of Tarikhuna and Tarikh, asking whether al-Miqdadi acknowledged Hitti's 1937 History of the Arabs, as well as the extent to which he was the heir of a later master Richard Hartmann. Finally it asks to what extent Arab nationalist history was an anecdotal, if ironic, offshoot of Orientalism.

Dyala Hamzah is Assistant professor of Middle East history at the University of Montreal. She holds a PhD in History and Islamic Studies (FreieUniversität Berlin, EHESS Paris). She recently published an edited volume with Routledge, entitled The Making of the Arab Intellectual. Empire, Public Sphere and the Colonial Coordinates of Selfhood (2012). Currently, she is completing a book manuscript entitled Muhammad Rashid Rida (1865-1935) or the 'Salafi Turn'. Public Interest, Islam and Public Opinion in Colonial Egypt.' 


\section{Zukunftsph ilologie}

\section{Tal Hever-Chybowski}

(Humboldt Universität zu Berlin)

The 'Zamlers' Scholarly Model: Mobilizing the East-European Jewish Masses for Philological Projects

Zamlers ("collectors" in Yiddish) were thousands of non- or semi-professional volunteers, mostly in Eastern-Europe, who, during the 20th century, gathered Jewish philological, ethnographic and historical material and sent it to scholars and research institutions. The mobilization of zamlers for the purpose of scholarly research can be traced back to the Russian historian Simon Dubnow, who, in 1891, issued a call to the Jewish literate masses of Russia to collect documentary material for a history of Eastern-European Jewry: "Not everyone who can read and write can be a brilliant writer or an historian," he wrote, "but every one of you can be a collector of material." Throughout the 20th century, scholarly projects of Yiddish philology, ethnography and historiography in Eastern-Europe would also mobilize zamlers for the production of scientific knowledge, which was seen as crucial for furthering the Jewish national cause. Between 1925 and 1939, as the Jewish Scientific Institute (YIVO) established a vast network of zamlers across Poland, Lithuania and Romania, the scholarly reliance on zamlers reached an extraordinary scale, amounting to "a virtual cult of documentary collection" (Fishman, 1996). Surveying key-events in the zamler tradition in modern Yiddish philology, this paper investigates the unique philological encounter between professional philologists and untrained zamlers and the ways in which this scholarly practice turns informants of philological research into knowledge-producing agents, thus blurring the distinctions between objects and subjects of scientific research. The exchanges between Yiddish philologists and their zamlers, scattered all over Eastern-Europe and crossing national boundaries, are shown to constitute a diasporic model of collective philological research, an alternative to centralized nation-state philological institutions of the time.

Tal Hever-Chybowski is a Ph.D. candidate at the History Department of Humboldt University, Berlin. He holds a B.A. in History from the Hebrew University of Jerusalem and an M.A. in History from the Humboldt University. He translated into Hebrew Edward Said's Representations of the Intellectual (1993), Mikhal Dekel's The Universal Jew: Masculinity, Modernity, and the Zionist Moment (2011), and is currently translating a forthcoming book on diaspora by Daniel Boyarin. $\mathrm{He}$ is founder and editor of the diasporic-Hebrew journal Mikan ve'eylakh in Berlin. His research topics include Jewish history, Yiddish philology, Hebrew, diasporism, draft evasion, conceptual history and the modern reception of antiquity.

\section{Sherif Hasan Ismail}

(New York University)

Philological Encounters, Literary Reconstructions: Fāris al-Shidyāq and His Career

From the late 1820 s and for almost three decades, the Lebanese-born Arab linguist and Renaissance figure Fāris al-Shidyāq (1805-87) had largely been working for Protestant missionary societies, mainly in Malta and in England, collaborating with various scholars and Orientalists in 


\section{Zukunftsph ilologie}

translating and editing religious and educational books and tracts, including a translation of the Bible into Arabic. Having been himself a grammarian, lexicographer, and/philologist, with knowledge of various languages, al-Shidyāq's extended encounter with Western scholars was often marked by difference, mutual criticism, conflict, challenge, complaint, and even dismissal and reinstatement. Such tension allows for an understanding of Orientalist scholarship not as an unobstructed and un-negotiated discursive practice, but as a collaborative endeavor in which neither the Oriental is a passive object of study, nor the Orientalist is an essentialized "homo orientalisticus", possessed /by an "Orientalist ego", dictating views and decisions. This collaborative practice is also shown to be marked by unequal power and knowledge positions, carried out within specific institutional frameworks, shaped by material determinants, and affected by personal interests and preferences, as well as linguistic and philological limitations. Al-Shidyāq records and reflects on his extended encounters with variety of scholars in two travel accounts, as well as in his autobiographical narrative Al-Sāq 'ala-I-Sāq (1855), which complements and parallels his travel accounts and includes further reflections in direct and straightforward prose, culminating in an appendix with extended philological analyses and critiques, but also through parody, metaphor, allegory, pun, and metathesis. While this paper examines al-Shidyāq's reflections on his encounters as recorded in all his writings, it focuses on Al-Sāq, which can be seen as both a representation of these encounters and a dramatized response to them, transforming the scholarly (and personal) experience into a literary and aesthetic experiment.

Sherif Ismail is a PhD student in Middle Eastern and Islamic Studies at New York University. He received his B.A. in English and M.A. in Comparative Literature, both with honors, from Ain Shams University in Egypt.

\section{Sarath Jakka}

(University of Porto/University of Kent)

Philological/Pedagogical Encounters: Charles Philip Brown and his Encounter with the Telugu Language

Present day biographies of Charles Philip Brown fit that most tendentious of stereotypes, that of the benevolent orientalist. Brown is famously credited with single-handedly rescuing the heritage of the Telugu language, the second most widely spoken language in India. As he says of himself, "Telugu literature was dying out; the flame was flickering in the socket. In 1825, I found Telugu literature dead. In thirty years I raised it to life". In India, region speaks before nation and so it is with the southern state of Andhra Pradesh where Telugu is spoken. Reflecting the political charge of cultures drawn on regional lines, Telugu publications to this day, celebrate the philological efforts of Brown whose grammars and lexicon are still widely used. He is touted as a compassionate administrator who averts famines, a passionate and selfless scholar who retains diligence despite eschewing pedantry, all this while carrying out his scholarly quests to the detriment of his career with the East India Company. I would like to bypass this hagiographic portrayal of Brown and re-investigate this particular 'encounter' with Telugu. In order to do this, 


\section{Zukunftsph ilologie}

I will focus on Brown's autobiographical work Narrative of the Literary Life of Charles Philip Brown and contextualize the 'philological self', depicted here and in many of his other writings, around pedagogical and professional concerns. A large part of Brown's selfnarratives consist of his frustrated attempts to learn Telugu. His project of amassing and recording manuscripts, of compiling grammars and lexicons is seen as arising out of his own stunted efforts to learn the language.

I would like to explore some of the interesting concerns that emerge in such motivations. How are different pedagogical cultures conceived of as bridging - or contributing to - the difference that is fundamental to a philological encounter? Here I will relate the instructional expectations that Brown carries with him and contrast it with the pedagogical culture he encounters in India while attempting to learn the language. I would also like to address Brown's relation with the East India Company. Here, romantic notions of the philological quest - and the self-fashioning resulting from it - come into conflict with the Company's 'colonial utilitarianism' (John Wilson, The Domination of Strangers). This raises questions regarding the complex forms the philological imperative might take when the romantic cult of the individual exceeds the abstracted requirements of a colonial administration.

Sarath Jakka is in the third year of his doctoral studies which he is jointly pursuing at the University of Kent and the University of Porto as a part of the Erasmus Mundus TEEME (Text \& Event in Early Modern Europe) program. His thesis looks at the ways in which ideas of colonisation and empire are articulated and justified in literary utopias written in early modern England. He will be exploring the specific strands of 'ideal politics' that are used to legitimate projects of territorial and epistemic colonisation in important literary utopias such as those by Thomas More, Francis Bacon and Henry Neville.

Before joining TEEME, he completed his undergraduate studies at St Stephen's College, Delhi, and his M.A in English Studies at The Central Institute of English and Foreign Languages, Hyderabad.

\section{Andrés Jiménez-Ángel}

(Katholische Universität Eichstätt-Ingolstadt)

Correspondence, "Cultural Pilgrimage" and the Transnational Legitimation of Philological and Linguistic Knowledge in Colombia, 1876-1911

During the last three decades of the nineteenth century and the first ten years of the twentieth a small group of Colombian intellectuals, formed around Miguel Antonio Caro, Rufino José Cuervo and Ezequiel Uricoechea, ended up being recognized as part of the most important linguistic and philological authorities in the Spanish speaking world. Through their research on Spanish language, aboriginal languages and Latin classics based on the premises of the historical and comparative study of language-a pioneering endeavor in a field dominated by the descriptive and normative grammatical tradition represented by the Real Academia-these intellectuals made themselves a name in the European community of philologists and linguists, particularly in Germany and France. Without denying the role that the quality of their work could have played, 


\section{Zukunftsph ilologie}

both their successful integration in these scientific networks and the privileged position they gained among the Spanish and Latin American letrados thanks to the European legitimation and validation of the philological and linguistic knowledge they produced resulted mainly from the strategic use of correspondence and of "cultural pilgrimage" in order to establish direct or epistolary contact with such prominent figures as August Friedrich Pott, Otto Ribbeck or Gaston Paris. Focusing on Rufino José Cuervo, in these paper I will briefly describe and explain the main features of this "strategy of communication" and I will try to show how the positive reception of the work of these Colombian intellectuals in Europe and the scientific exchange which derived from it contributed to a change in their understanding of language in general, of the Spanish language in America and to questioning the extent and the legitimacy of the authority of the Real Academia.

Andrés Jiménez-Ángel studied History and Law at the Universidad de Los Andes, Bogotá (LL.B. and M.A.) and the Universität Bremen, Bremen (LL.M.Eur). He is currently a graduate student and research fellow (wissenschaftlicher Mitarbeiter) at the Chair of Latin American History, Katholische Universität Eichstätt-Ingolstadt.

\section{Albert de Jong \\ (Leiden Institute for Religious Studies) \\ Lawrence Heyworth Mills (1837-1918) and his Zoroastrian Catechism}

In spite of his appalling reputation among specialists, many of the works of L.H. Mills (the only professor of Zend (= Avestan) philology the Western world has ever known) have been in print since their publication. Mills' gargantuan oeuvre is characterized by a burning desire for recognition as a philologist, which he tragically never achieved in the West. He built up a reputation, however, among the Parsis, the Zoroastrians of India, who invited him to write for them a catechism of their own religion. When he had done this, they too hesitated to publish it, for it was deemed too difficult for ordinary readers. The work was eventually published (An Exposition of the Lore of the Avesta in Catechetical Dialogue, Bombay 1916), and even reissued in the 1960s. The paper will address the genesis of the work in its multiple contexts: that of the Parsis, of western Orientalism and of modernist theology, which formed the backbone of Mills' idiosyncratic views.

Prof. Dr. Albert de Jong is Lecturer in Religious Studies and teaches courses on the academic study of religion on various levels, as well as courses on the history of religions of the ancient world. The main focus of his research is the religious history of Iran, from the earliest period to the present. De Jong studied Theology and Persian in Utrecht and Old and Middle Iranian languages at the School of Oriental and African Studies, University of London. He obtained his Ph.D. from the University of Utrecht in 1996, with a dissertation on Zoroastrianism in Greek and Latin literature (publ. 1997). He was a Golda Meir Post-Doctoral Fellow at the Hebrew University of Jerusalem (1996-1997) and has been in Leiden since 1997, first as a post-doctoral researcher and from 1998 as lecturer in Religious Studies. 


\section{Zukunftsph ilologie}

His current research project is "The Religious History of the Sasanian Empire (224-642 ce)." This will be the fifth volume in the series A History of Zoroastrianism and will cover not not just the history of Zoroastrianism by itself, but also the interaction between Zoroastrians, Christians, Jews, Manichaeans, and Mandaeans in a crucial period of their development. These communities are all served by a considerable body of scholarly/literature and by ongoing scholarly attention, but often in regrettable isolation from the wider context. It must be clear that one cannot understand the Babylonian Talmud without knowledge of Sasanian law and institutions any more than one can study the development of Zoroastrianism without taking into account the challenges of Manichaeism and Christianity. In order to do justice to the subject, therefore, two volumes are in preparation: one that follows the history of Zoroastrianism from the rise of Ardashir up to the Arab invasions, and a separate volume that will offer a "profile" of Sasanian Zoroastrianism in the multiple contexts of the Empire.

\section{Ammeke Kateman}

(University of Amsterdam)

Discussing Religion Globally. An Encounter between Muhammad 'Abduh, Herbert Spencer and Wilfrid Blunt

In the summer of 1903, the Islamic reformer Muhammad 'Abduh, Grand Mufti of Egypt, visited the home of scholar Herbert Spencer in Brighton, only a few months before the latter's death. 'Abduh had especially come to England for this visit, to which his old friend the English poet and writer Wilfrid Blunt accompanied him. The three intellectuals discussed the corruptive force of materialism in contemporary society, lamenting the loss of morals and the rise of international aggression accompanying it, and inquired about each other's conceptions of God. Meeting each other in the age of colonialism, they explored and compared their ideas about religion, religious truth and the place of religion in modern society.

This paper seeks to analyze this encounter, as narrated by both Blunt and 'Abduh, but conveyed by 'Abduh's editor and biographer Rashid Rida in the latter case. Drawing upon Dietrich Jung's recent Orientalists, Islamists and the Global Public Sphere, it considers this interaction as part of a merging global public sphere, in which globally converging concepts inform globally interconnected individuals - yet with due consideration of the local contexts and semantics to which these individuals were always also tied. By examining how 'Abduh, Spencer and Blunt assessed the differences and similarities between each other's religions and each other's religious convictions, this paper relates their discussion to a globally converging though not singularly defined concept of 'religion' - a key concept to understand both the self and the other in a colonized world. A concept, therefore, which authors such as Talal Asad, Richard King and David Chidester consider formative in interrelated and partially overlapping academic fields such as anthropology, Orientalism and the comparative study of religion, but which, as Jung convincingly argued, equally informed the discourse of the ones studied. 


\section{Zukunftsph ilologie}

Ammeke Kateman (1985) obtained a BA degree in Arabic Language and Culture as well as in History at the University of Amsterdam. Focusing on Muhammad 'Abduh's thought and his intellectual context, she completed her MA degree in History (Research Master) with distinction at the same university in 2010.

Supported by the Netherlands Inter-University School for Islamic Studies (NISIS), she currently conducts a PhD-research project, preliminarily titled 'Defining Islam as a Religion. Muhammad 'Abduh and his Interlocutors', under the supervision of Professor Gerard Wiegers and Dr Richard van Leeuwen (both Religious Studies, University of Amsterdam).

\section{Göran Larsson}

(University of Gothenburg)

\section{H.S. Nyberg's Encounter with Egypt and the Mu'tazili School of Thought}

In 1923 the famous Swedish Orientalist Henrik Samuel Nyberg (1889-1974) was rewarded with a large scholarship that enabled him to travel to Istanbul and Cairo. This was his first visit to the Orient and the aim of the trip was to improve his skills in the Arabic language and to study the so-called early Islamic sects. In 1924 Nyberg embarked on his scientific journey and left his wife back in Sweden together with their newborn son. Besides studying the Arabic language he was able to find an unpublished text of the "great mu'tazili theologian al-Khayyat" and his refutation of Ibn ar- Rawandi's critique against the mu'tazilities. The MS that was found in the library of alAzhar was known as Kitab al-Intisar. With the printing of the text, Nyberg became a well-known expert and he was, for example, responsible for the entry on the mu'tazili in The Encyclopaedia of Islam. Nyberg's edition and lengthy preface of al-Khayyat was also translated and published in French by Albert Nader under the title Le Livre du Triomphe.

By the help of Nyberg's unpublished letters that were sent to his friends, colleagues and family in Sweden, the aim of my presentation is to cast light on how the editing process and the discovery of the above named manuscript was communicated, discussed and reported back to Sweden. Besides scientific information about the text the letters also contains information about Nyberg's perceptions of Egypt, Islam and the Muslim reformists that were active in Egypt from the end of the nineteenth century up till his stay in Egypt in 1924. I want to address in what ways his visit to Egypt and his encounters with the Muslim theologians at the al-Azhar university had an impact on his way of thinking about philology, science and especially the study of Islam and Muslims. Quite interestingly, Nyberg's encounter with the mu'tazili school of thought and the Muslim reform thinkers was also related and interpreted in the light of contemporary Christian debates concerning how to interpret the Bible in Sweden and Europe. From this point of view, Nyberg's visit to Egypt in 1924 can truly be interpreted as an illustrative case of both a philological and intellectual encounter between the East and the West. His travel was also of great importance for the study of Oriental languages in Sweden and the visit to Egypt both established and confirmed old and new relationships between Swedish and Egyptian scholars and institutions. 


\section{Zukunftsph ilologie}

Göran Larsson is a senior lecturer in Religious Studies. While his research is focused primarily on Islam and Muslims in Europe, he has also written about Islamic theology, Quranic studies and issues related to religion and the media. In addition to his academic work he was also secretary to the Ministry of Education's 2008-2009 inquiry into the training of Imams in Sweden. His most recent publications are the edited volume, Muslims and the New Information and Communication Technologies: Notes from an Emerging Field, published by Springer in 2013 (edited together with Thomas Hoffmann) and Muslims and the New Media: Historical and Contemporary Debates, published by Ashgate in 2011. Göran Larsson also collaborated with professor Åke Sander on the publication Islam and Muslims in Sweden: Integration or Fragmentation? A Contextual Study, published by Verlag in 2007.

Although Göran Larsson did his PhD in Religious Studies at the University of Gothenburg, he also held positions at Uppsala University and Södertörn University, and has been a guest researcher at the University of Leiden in the Netherlands. He is also currently affiliated with the Department of Culture Studies and Oriental Languages at the University of Oslo. Göran Larsson is conducting research into Muslim Tatars in the Nordic and Baltic Countries and into Muslims in Europe (especially in Sweden). He is contracted as the responsible editor of a volume for Brill's Index Islamicussupplement series (on Islam and Muslims in the Nordic and Baltic Countries). From September 1st 2012 until the summer 2014 Göran Larsson will work 30 percent as a researcher for the governmental body SST, the Swedish Commission for Government Support to Faith Communities. His research for SST will be focused on Islam and Muslims in Sweden and Europe.

\section{Herman Paul}

\section{(Leiden University)}

Contested Visions of Oriental Studies: The Polemical Reception of Reinhart Dozy's 'The Israelites in Mecca' in the 1860s

What happens to our understanding of nineteenth-century Oriental studies, asks Suzanne Marchand, if we abandon the "winner's history" perspective that has dominated the history of Oriental studies, or the history of scholarly disciplines in general, for so long? As demonstrated by her German Orientalism in the Age of Empire (2009), one clear effect is that processes of "professionalization" or Verwissenschaftlichung no longer appear as self-evident. Focusing on "the difficulties, intellectual and institutional, of being a German orientalist in the middle of the nineteenth century" (103), Marchand shows how contested, in fact, "professionalization" was, especially among a mid-nineteenth-century generation of Orientalists, whom Marchand describes as being "caught between romanticism and historicism, between its grand political and aesthetic dreams and its desire to be counted wissenschaftlich" (138).

Building on Marchand's work, this paper argues that mid-nineteenth-century Orientalists not only found themselves caught between romantic dreams and scientific facts, but also articulated their visions of Oriental studies as a scholarly discipline within the contexts of two other types of tension. While the first of these - tensions stemming from conflicting political and, especially, religious agendas underlying the study of the Ancient Near East - was neither new nor unique, the second one can be seen as typical for their time. This was a gradual exchange of the library 


\section{Zukunftsph ilologie}

as a privileged site of (philological) knowledge production for the archival journey or field trip as most appropriate means of knowledge acquisition. A field of study based on books and manuscripts in Western collections gradually transformed itself into a field committed to scientific travel and investigation in situ.

The thesis defended in this paper is that these mid-century tensions and uncertainties added urgency to the question what counted as proper scholarly work in the field of Oriental studies. What were the standards that scholarly publications had to meet, or the skills and virtues that Orientalists had to master?/In general, the urgency of the question is reflected in the great amount of attention that book reviews and scholarly correspondences from the mid-nineteenth century paid to issues of scholarly conduct, the dangers of dilettantism, and/or the deadlock of "hypercritical" treatment of source material (see, e.g., the Snouck Hurgronje-Nöldeke correspondence published by Pieter van Koningsveld). Arguably, however, uncertainty and lack of agreement over scholarly standards became most clearly visible in controversies - perhaps especially in controversies in which respected scholars found themselves taking diametrically opposed positions.

Concretely, this paper examines what the surprise, enthusiasm, anger, and embarrassment created by the publication of Reinhart Dozy's De Israëlieten te Mekka (1864) tells us about what counted as proper scholarly conduct in Oriental studies in the 1860 s. While the Jewish reception of Dozy's remarkable book has admirably been traced by Ran HaCohen, in Reclaiming the Hebrew Bible (2010), this paper argues that Dozy's hypotheses about Mecca (founded by a Jewish tribe) and Abraham (the name of an ancient stone god) forces especially his close colleagues and students, in the Netherlands and elsewhere, to explicate their views on how to study the early Islam or the Hebrew Bible. To that end, the paper does not merely classify who were "for" and "against" Dozy's book, or from what sort of ideological positions scholars such as Friedrich Wilhelm Graf, John William Colenso, Abraham Kuenen, Michael Jan de Goeje, Christiaan Snouck Hurgronje, and others responded to Dozy, but examines in detail what critics of Dozy's Israellieten te Mekka expected Orientalists to do - what sort of sources they were supposed to use, what sort of methods they had to employ, and what sort of conduct they had to display in order to count as wissenschaftlich.

The paper, in short, presents a case study of a field in transition. It shows how unstable standards of scholarly performance were in absence of a leading paradigm, how scholarly expectations varied along ideological and generational lines, and how decisively the field of Oriental studies changed from a library-based science to a travel-oriented branch of scholarship in, roughly, the years between Dozy's Israëlieten te Mekka (1864) and Snouck's Het mekkaansche feest (1880).

Herman Paul is a lecturer in historiography and philosophy of history at Leiden University, where he directs a NWO-funded (VIDI) research project on "The Scholarly Self: Character, Habit, and Virtue in the Humanities, 1860-1930." A member of The Young Academy (KNAW), the International Commission for the History and Theory of Historiography, and the editorial board of Tijdschrift voor Geschiedenis, Paul also holds a special chair in secularization studies at the University of Groningen. Among his publications are Hayden White: The Historical Imagination (Polity Press, 2011), Key Issues in Historical Theory (Routledge, forthcoming), and about two 


\section{Zukunftsph ilologie}

dozens of articles on historiography, philosophy of history, and the history of the humanities in such journals as History and Theory, History of the Human Sciences, Rethinking History, and the Journal of the Philosophy of History.

\section{Pascale Rabault-Feuerhahn - convener}

(CNRS Paris)

Pascale Rabault-Feuerhahn is a tenured Researcher at the Centre national de la recherche scientifique in Paris, in the research unit «Pays germaniques: transferts culturels». After she graduated in German studies (Sorbonne and Ecole normale supérieure) and Modern Indology (Ecole des langues orientales) she completed her PhD on the history of Indology and comparative linguistics in Germany (Université Aix-Marseille I, 2005).

Her areas of specialization include the history of the human sciences, especially the history of Oriental philology. The ethnographical and anthropological aspect inherent to the philological work is a major focus of her research. She currently works on the history of the comparative method in the human sciences, connected with the development of Oriental studies. In a more contemporary perspective, she also analyses the reconfiguration of the comparative paradigm in the context of postcolonial studies.

Her publications include L'archive des origines. Sanskrit, philologie, anthropologie dans l'Allemagne du XIXe siècle (Paris, Cerf 2008) and Itinéraires orientalistes entre France et Allemagne (Revue germanique internationale 6/2008).

\section{Umar Ryad - convener}

(University of Utrecht)

Umar Ryad is associate professor of Islamic Studies, University of Utrecht. Since 2008, he has been working as assistant professor of Islamic Studies at Leiden University. He studied at alAzhar University in Cairo (BA Islamic Studies in English, 1998) and obtained his MA degree in Islamic Studies (cum laude) from Leiden University (2001), where he also received his PhD degree with the thesis Islamic Reformism and Christianity: A Critical Study of the Works of Muhammad Rashid Rida and His Associates (1898-1935) (2009). His current research focuses on the dynamics of the networks of Islamic reformist and pan- Islamist movements, Muslim polemics on Christianity, the history of Christian missions in the modern Muslim World, and transnational Islam in interwar Europe. He has recently received an ERC Starting Grant (20142019) for the study of Muslim Networks in Interwar Europe and European Trans-cultural History. 


\section{Zukunftsph ilologie}

\section{Mishka Sinha}

(Zukunftsphilologie Fellow 2013-2014, Berlin)

"And shall all these die for me and mine?" A new Ethics for the Gita: Josiah Royce, Indic Philology and Post-Kantian Idealism in the United States, 1876-1916

In 1876, following his post-graduate studies in Germany, Josiah Royce (1855-1916) returned to study philosophy and philology towards a doctoral degree at the new Johns Hopkins University (JHU), Baltimore. Royce would become the foremost American exponent of Absolute Idealism, though his later work registered the impact of Pragmatism. Royce's reputation declined after his death, yet he was extraordinarily influential in his time, making his mark on William James, T.S. Eliot and George Santayana among others. In Germany, Royce had encountered comparative philology and Sanskrit. At JHU he registered for C.R. Lanman's Sanskrit courses but also arranged for a separate five-month course concentrating only on reading the Bhagavad-Gita. In 1882, Royce joined the philosophy faculty at Harvard. His seminal work, The World and the Individual (1898-99) famously elucidates his interest in Indian philosophy. Yet the Bhagavad-Gita continued to have a special significance for Royce, as evinced in his last seminar in Metaphysics at Harvard in 1915-16. Here, he offered a summary of his extraordinary interpenetration of the Gita's soteriological message with Kantian ethics, read in conjunction with eminent texts drawn from Royce's American and transnational cultural and intellectual inheritance.

This paper will analyse Royce's engagement with The Bhagavad-Gita in the intellectual and cultural contexts of JHU and Harvard, and their institutional integrations of philosophy, philology and Sanskrit. These universities were strongly influenced by the German research model; at both institutions philosophers and philologists were legatees of the European traditions they had studied within - Royce's teacher Lanman and Lanman's teacher Whitney, for example, were both taught by Roth and Weber. While Royce's engagement with Indian philosophy is the subject of several studies, the conjunctions and correspondences between his philological and philosophical studies within the context of the intellectual traditions he inherited and the institutional milieu he inhabited remain little examined. Further, his unique critical comprehension of the Gita's ethical lesson in his 1915-16 lectures has not received scholarly attention.

Mishka Sinha is a Zukunftsphilologie Fellow at the Forum Transregionale, Berlin and affiliated with the Friedrich Schlegel Graduiertenschule, Freie Universität, Berlin. In 2012-13, she was a Postdoctoral Research Associate at the Centre of South Asian Studies, Cambridge. She was educated at St. Xavier's College, Bombay, Lady Margaret Hall, University of Oxford, Emory University, Atlanta, GA, and the University of Cambridge. She is currently working on the book manuscript of her doctoral thesis on the history of the transmission of Sanskrit in Britain and America, 1832-1939. Her other research projects include an article on transcultural translations of the Upanishads in the nineteenth and twentieth centuries, and a larger project on Oriental publishing in the west in the long nineteenth century. Her previous articles on the translation of the Bhagavad Gita and on Edward Said and American Orientalism were published in the academic journal Modern Intellectual History (2010), and in Z. Elmarsafy, A. Bernard, D. Atwell (eds.), Debating Orientalism (Palgrave Macmillan, 2013), respectively. 


\section{Zukunftsph ilologie}

Mishka Sinha's research interests are in the intellectual history of empire and colonialism, the cross-cultural transfer and transformation of ideas, and nineteenth and early twentieth century literary history. At Cambridge she has taught Modern South Asian History for the History Tripos, and the British Empire in the nineteenth century for The Corpus Christi Lifelong Learning Programme.

\section{Rico Sneller}

(Leiden University)

Heidegger and the Japanese Notion of 'Language'

In a famous dialogue with a Japanese philosopher regarding 'language', Heidegger seems reticent as to imposing Greek conceptuality on Japanese thinking, especially on language ('Gespräch mit einem Japaner über die Sprache'). The famous Kyoto school, and many Japanese philosophers in its trail, have not eschewed reconsidering Japanese thinking in predominantly Greco-European categories, even reinterpreting it in terms of these same categories. The dialogue's interlocutors, presumably Heidegger himself and the Japanese professor Tezuko from the Imperial University of Tokyo, discuss language as a mystical secret rather than as a 'tool' for common communicative 'usage'. Not without reluctance, the Japanese philosopher finally yields to his interlocutor's demand to reveal the Japanese expression for 'language': koto ba. This notion, interestingly, evokes the budding of petals in light of the 'frameless'.

Remarkably, in Japanese philosophy an explicit reflection on language started only in the 70s of the 20th Century. In my contribution I intend to comparatively study the question as to in how far both Heidegger's and some Japanese philosophers' (e.g. Ueda Shizuteru's and Omori Shozo's) notion of language affects their idea about 1) knowledge (if not 'science'), and 2) philology. For if conceptions of language are basic, as Heidegger claims, they cannot but affect ideas about knowledge and concept formation.

Dr. H.W. (Rico) Sneller (1967) is assistant professor of philosophical anthropology at the Institute for Philosophy at Leiden University. He studied theology in Utrecht and Leiden and philosophy in Paris. His dissertation dealt with the problem of negative theology and the philosophy of Jacques Derrida.

(Stand: $14.04 .2014 \mid$ Dayeh/Klaubert) 


\section{Zukunftsph ilologie}

The research program ZUKUNFTSPHILOLOGIE supports research in marginalized and undocumented textual practices and literary cultures with the aim of integrating texts and scholarly traditions from Asia, Africa, and the Middle East as well as from Europe itself, by way of a critical recuperation of the practice of philology. The program takes as its point of departure the increasingly growing concern with the global significance of philology and its potential to challenge exclusivist notions of the self and the canon. Zukunftsphilologie is based at the Freie Universitaet Berlin and is a research program at the Forum Transregionale Studien. It is supported by funds from the Land Berlin. For further information, please visit: www.zukunftsphilologie.de

The Leiden University Centre for the study of Islam and Society (LUCIS) is an interdisciplinary and interfaculty centre that brings together researchers from the Faculty of Humanities, the Leiden School of Law and the Faculty of Social and Behavioural Sciences. The aim of LUCIS is to develop and strengthen teaching and research on Islam and Islamic societies. LUCIS also facilitates and contributes to public debate and policy making with regard to Islam. LUCIS's aim is to strengthen Islamic studies in Leiden. LUCIS organizes lectures and symposiums on current research projects that target both specialists and stakeholders. LUCIS also brings together existing expertise into new research projects. LUCIS awards grants to young and senior members of academic staff for their research at Leiden University.

For further information please visit:

http://www.research.leiden.edu/research-profiles/amt/centres/lucis.html

The Forum Transregionale Studien is a Berlin-based research platform designed to promote research that connects systematic and region-specific questions in a perspective that addresses entanglements and interactions beyond national, cultural or regional frames. The Forum works in tandem with already existing institutions and networks engaged in transregional studies and is supported by an association of directors of universities, research institutes and networks mainly based in Berlin. The Forum Transregionale Studien is funded by the Land of Berlin and the German Federal Ministry of Education and Research.

For more information, please visit: www.forum-transregionale-studien.de

\section{Forum Transregionale Studien}

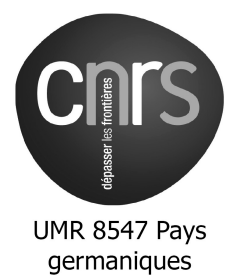

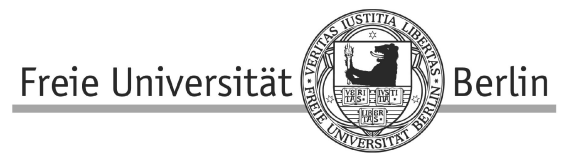
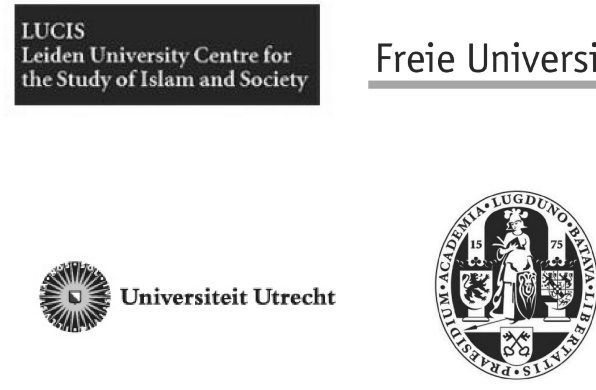

Universiteit Leiden 